\title{
Anomalies, Aneurysm and Histology of the Middle Cerebral Artery in Nigerian Africans
}

\author{
Anomalías, Aneurisma e Histología de la Arteria Cerebral Media en Africanos Nigerianos \\ "Idowu, O. E.; ${ }^{* *}$ Shokunbi, M. T.; ${ }^{* *}$ Malomo, A. O. \& ${ }^{* * *}$ Akang, E. E. U.
}

IDOWU, O. E.; SHOKUNBI, M. T.; MALOMO, A .O. \& AKANG, E. E. U. Anomalies, aneurysm and histology of the middle cerebral artery in Nigerian Africans. Int. J. Morphol.,26(4):1023-1027, 2008.

SUMMARY: The histology of the middle cerebral artery (MCA) in Nigerian Africans has not been previously studied. One hundred MCAs obtained at autopsy from fifty adult Nigerians were studied. The vessels were processed and stained with Ehrlich's haematoxylin and eosin, elastic Van Gieson and Masson's trichrome stains. Early branches were given off before the perforators in two middle cerebral arteries, and there was one accessory MCA, making an incidence of anomalies of 3\%. No aneurysm was observed in any of the cases. The internal elastic laminas were well developed but the external elastic laminas of the vessels were poorly developed. Close to the bifurcations the tunica media tapered gradually and at the bifurcations, the tunica media was completely deficient being replaced by the tunica adventitia (Forbus raphé). The tunica adventitia was thicker at the bifurcations $(0.21 \mathrm{~mm})$ compared to other sites of the vessel. The average thickness of the MCA tunica media at its origin was $0.12 \mathrm{~mm}$ while that of the tunica adventitia was $0.10 \mathrm{~mm}$. These results are similar to what has been described in the literature for Caucasians. It buttresses the assertion that anatomical anomalies of the MCA are rare. The seemingly low frequency of MCA aneurysms in Nigerian Africans is not due to its anomalies or histology.

KEY WORDS: Anomalies; Histology; Middle cerebral artery.

\section{INTRODUCTION}

In most populations, the MCA is a frequent site for cerebral aneurysms. However, the relative frequency of MCA aneurysms (MCAAs) varies according to the nature of the study and among different populations. In a clinical series of 1314 consecutive patients with cerebral aneurysms, from a catchment area in Finland with a population of 870,000 , MCAAs were present in 561(43\%), (Rinne et al., 1996). In the Japanese, MCAAs make up nearly a quarter $(23.5 \%)$ of intracranial aneurysms (Hosada et al., 1995) while amongst the Taiwanese, cerebral aneurysms are located in the distributions of the MCA in about a fifth (19.6\%) of patients (Howng et al., 1995). The relative incidence among Caucasians is similar (Picard et al., 1996). In an autopsy study of the circle of Willis of 1021 cadavers in India, only two aneurysms were found (Bombay Hospital Institute of Medical Sciences, 1993). Eighty-one percent of the MCAAs in Rinne's series were located at the vessel's bifurcation (Rinne et al.).

The current theories for the pathogenesis of intracranial saccular aneurysms propose either a congenital or a degenerative basis for the development of aneurysms (Taylor et al., 1995). Cerebral arteries have been shown to possess a poorly developed external elastic lamina and adventitia, thin media and defects in the media termed Forbus raphés (Forbus, 1930; Finlay \& Ganhan, 1994; Laadzinki et al., 1996). The number of raphés increases with age (Glynn, 1940; Stehbens, 1963).

Micro-surgical techniques have now made reconstruction of a bypass to the MCA an important method of preserving and restoring blood flow to the cerebrum. The increasing use of surgical magnification for operation in the territory of the MCA has created a need for a better understanding of its anomalies.

The purpose of this study was to determine the frequency of MCA anomalies, aneurysms and describe the histological pattern of the MCA.

\footnotetext{
* Neurosurgery Division, Depart. of Surgery, Lagos State University College of Medicine and Lagos State University Teaching Hospital, Ikeja, Lagos, Nigeria. ** Departments of Neurosurgery.

**** Pathology, University College Hospital, Ibadan, and College of Medicine, University of Ibadan, Nigeria.
} 


\section{MATERIAL AND METHOD}

The target population for this study was a cohort of fifty Nigerian adults eighteen years and above who had successive postmortem examination at the Pathology Department of University College Hospital (UCH), Ibadan, Nigeria.

Information regarding demography and medical history were obtained from case notes of subjects enrolled into the study. Cases with an ante-mortem or post-mortem evidence of meningitis or atherosclerosis were excluded.

The subjects' brains were fixed in 10 percent formalin immediately after post-mortem examination. Gross examination of the specimens was performed with a X5 magnifying lens. The arachnoid membrane was dissected off the cerebral hemispheres for proper visualization and identification of the vessels. The MCAs were injected with Congo red dye after adequately ligating the distal one-third of the internal carotid artery (ICA) and the proximal one-third of the posterior communicating artery. The MCA was dissected from its origin to the termination of each cortical branch. The four segments of the MCA namely, sphenoidal (MI), insular (M2), opercular (M3) and the cortical (M4) segments were first identified. The anomalies were studied and recorded by free-hand line drawing and photography.

After the morphologic examination, the vessels were returned to the $10 \%$ formalin and subsequently processed by dehydrating with graded concentrations of alcohol, clearing with xylene and impregnation with paraffin wax. Representative histological sections were stained with Ehrlich's haematoxylin and eosin, elastic Van Gieson's and Masson's trichrome stains.

\section{RESULTS}

Seventeen female and thirty-three male brains were examined. The male: female ratio was 1.9:1. The mean age for males was 42 years and 49 years for females. The mean age for both sexes was 44 years.

One hundred MCAs were noted and examined. The origin of the MCA was located inferior to the anterior perforated substance, posterior to the olfactory trigone and lateral to the optic chiasma. It passed inferior to the anterior perforated substance and then superiorly and laterally, deep into the island of Reil.
In one hemisphere, an accessory MCA was found arising from the anterior cerebral artery, medial to the recurrent artery of Heubner. The recurrent artery of Heubner (medial striate artery) entered the anterior perforated substance while the accessory MCA coursed lateral to the anterior perforated substance to send branches to the ipsilateral frontal operculum normally supplied by the MCA. Early branches were given off before the perforators in two cerebral hemispheres. There was no duplicate MCA arising from the internal carotid artery. There was also no aneurysm.

Histological review of the MCA revealed the presence of well-developed internal elastic lamina, tunica media and tunica adventitia. The external elastic laminas were poorly developed. Close to the bifurcations, the media tapered gradually. At the bifurcations, the tunica media was completely deficient being replaced by the adventitia (Fig. 1). The tunica media was just slightly thicker than the adventitia except at bifurcation sites where the tunica media is completely deficient. The average thickness of the MCA tunica media at its origin was $0.12 \mathrm{~mm}$ (Standard error of mean $(\mathrm{SEM})=3.24 \times 10-3)$ while that of the tunica adventitia was $0.10 \mathrm{~mm}$ (SEM $=3.55 \times 10-3)$. The tunica adventitia was thicker at the bifurcations $(0.21 \mathrm{~mm}, \mathrm{SEM}=3.16 \times 10-3)$ compared to other sites of the vessel $(\mathrm{p}<0.05)$.
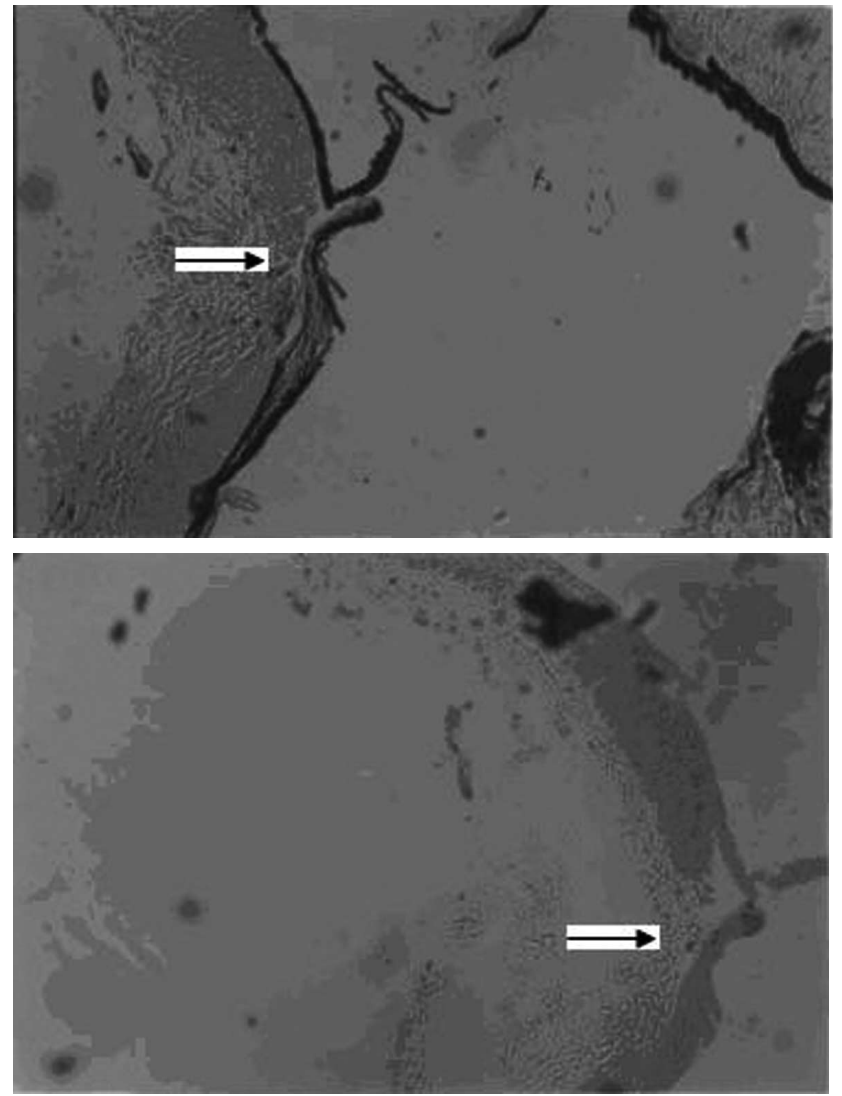

Figure 1: Middle cerebral artery histology at its bifurcation, showing media defect at its bifurcation (arrow). 
IDOWU, O. E.; SHOKUNBI, M. T.; MALOMO, A .O. \& AKANG, E. E. U. Anomalies, aneurysm and histology of the middle cerebral artery in Nigerian Africans. Int. J. Morphol.,26(4):1023-1027, 2008

\section{DISCUSSION}

In $2 \%$ of our cases, the early branches (MCA cortical branches given before it trifurcates or bifurcates) were given off before the perforators; The MCA perforating branches arose from the superior trunk of a bifurcated MCA in one of these cases. There was no duplication of the MCA in our series. Crompton found anomalies of the MCA in 3.2\% of 347 hemispheres, ten of these were duplicated MCA and one was an accessory MCA (Crompton, 1962). Jain recorded an incidence of $3 \%$ in his study of 300 hemispheres (Jain, 1964). One accessory MCA (1\%) was noted in the same study. These observations further buttress the asserted rarity of anomalous MCA in general, our environment inclusive.

The MCA is a muscular artery and muscular arteries generally have the same basic composition as elastic arteries but the elastic tissue is reduced to a well-defined, fenestrated elastic sheet, the internal elastic lamina, in the tunica intima, and a diffuse external elastic lamina in the tunica adventitia. The tunica media is mainly composed of a thick layer of smooth muscle. It has collagen and elastin scattered within the tunica media. These are fibrous proteins primarily responsible for the strength of the vessel wall. The vasa vasorum are mainly confined to the adventitial layer, although small branches may extend into the tunica media. All the MCA vessels reviewed revealed poorly developed external elastic lamina and a relatively thinner tunica media compared to other extracranial muscular arteries. In 1930, Forbus drew attention to interruptions of the media in the crotch of cerebral and extracranial arterial forks of infants. At such sites an adventitial wedge extends to the internal elastic lamina, interrupting the media. Calling them "congenital medial defects," he inferred without evidence that they were loci minoris resistentiae where aneurysms could develop. No distinct media was discernible histologically in most of these aneurysms, so he assumed that they developed from "medial defects." It was suggested that medial defects should be called "medial gaps" because no functional deficiency is suggested by the name; however the term, "medial raphés" would be more appropriate because it also indicates their functional role (Stehbens, 1989).

Medial defects were noted in all the vessels examined in the present study. In acute angles the medial muscle in the adjoining walls would tend to pull virtually in opposite directions during vasoconstriction, and in biology where this occurs there is usually a bone, ligament, or raphé for muscle fiber attachment (Stehbens, 1989). This concept is consistent with their propensity for acute angles at the apex or lateral angle of the fork. The raphé acts in the capacity of a sheet anchor for the muscle. It could act as reinforcement, like the prow of a boat, but if this is so, the absence of raphé at obtuseangled forks requires explanation.

It has been demonstrated that medial gaps increase in frequency with age, proving that some at least are acquired (Glynn). In older individuals they are wider and denser than in the fetus or infant (Stehbens, 1963). Moreover, their prevalence in acute angles, whether at the apex or the lateral angle of a fork or union, suggests that mechanical factors are important in their localization.

Study of early aneurysm formation indicated that preaneurysmal mural thinning or microevagination often occurred to the side of the apical raphé which, if involved in the pathogenesis of aneurysm formation, was involved fortuitously and "taken up" into the expanding aneurysm wall rather than always being the initiation site of the sac (Stehbens, 1963). There was no evidence that Forbus' raphés enlarged to become preaneurysmal lesions such as mural thinning or infundibular dilatations. Moreover, the entrance to most cerebral aneurysms is considerably wider than are medial defects, so the relatively abrupt media termination at the sac entrance must be acquired.

No evidence exists to demonstrate that medial defects or raphés are loci minoris resistentiae. Their location, ubiquity, and morphology are all inconsistent with this assertion or that they play a causative role in aneurysm formation.

The theories for the pathogenesis of intracranial aneurysms (including middle cerebral artery aneurysms) propose a congenital or acquired cause. Although genetic factors may be involved in cerebral aneurysms formation (Coutard \& Osborne-Pellegrin, 1996), cerebral vascular bifurcations have been shown to possess certain characteristics (poorly developed external elastic lamina and adventitia, thin media and defects in the media) (Forbus; Finlay \& Ganhan; Laadzinki et al.), which increase with age (Glynn; Stehbens, 1963).

Based on similar microscopic features of cerebral vascular bifurcation and trunk in our population with the Caucasians, the cause of this discrepancy in the incidence of cerebral aneurysm is not due to histological differences. This suggests the role of acquired factors.

Some of the known risks factors for the development and rupture of intracranial aneurysms include hypertension, smoking, high cholesterol intake, sickle cell anaemia, 
bacteraemia, trauma, connective tissue disorders, metastatic lesions to the brain and radiotherapy (Taylor et al., 1995; Sacco et al., 1984; Knekt et al., 1991; Oyesiku et al., 1991; Diggs \& Brookoff, 1993; Juvela et al., 1993; Adamson et al., 1994; Schievink et al., 1996). These risk factors are very much present in our population (Johnson, 1971; Taylor \& Agbedana, 1983). Despite this, intracranial aneurysms seem relatively uncommon in Nigeria.

Approximately 12 percent of patients with intracranial aneurysms die before receiving medical attention (Schievink, et al., 1995). Forty percent of those hospitalized die within one month after the event (Sacco et al.; Phillips et al., 1980; Longstreth et al., 1993; Fogelholm et al., 1993; Inagawa et al., 1995). Hence, many patients will die before they get to a tertiary hospital. In our environment, access to orthodox medicine though relatively available is not usually the first point of call during illnesses. Hence, patients presenting with cerebral aneurysms, ruptured or prior to rupturing, may die before getting appropriate medical attention. In addition, in our environment, neurosurgeons and neurologists are very few. Autopsies are hardly performed following deaths that occur at home or at primary or secondary hospitals. This is largely due to religious beliefs, over stretched post-mortem facilities and paucity of pathologists. The apparent rarity of aneurysms in our sample may also partly be attributable to by low autopsy rates in our local population.

In conclusion, the anomalies and histology of the MCA of the Nigerian African is similar to that of the Caucasian. MCA aneurysms are relatively uncommon at autopsy in our environment. The reason for this seemingly low incidence of MCA aneurysm in this study is unlikely to be due to the morphological or histological pattern of this vessel.

IDOWU, O. E.; SHOKUNBI, M. T.; MALOMO, A .O. \& AKANG, E. E. U. Anomalías, aneurisma e histología de la arteria cerebral media en Nigerianos africanos . Int. J. Morphol., 26(4):1023-1027, 2008.

RESUMEN: La histología de la arteria cerebral media (ACM) de los africanos de Nigeria no ha sido previamente estudiada. Fueron examinadas $100 \mathrm{ACM}$, obtenidas en autopsias de 50 individuos nigerianos adultos. Las arterias fueron procesadas y teñidas con hematoxilina y eosina de Ehrlich, Van Gieson para fibras elásticas y tricrómico de Masson. Ramas proximales se originan antes de la división en dos arterias cerebrales medias, y había una ACM accesoria, constituyendo una incidencia de anomalías del 3\%. No se observó aneurisma en ninguno de los casos. La lámina elástica interna estaba bien desarrollada, pero la lámina elástica externa de los vasos estaba pobremente desarrollada. Cerca de la bifurcación la túnica media es gradualmente cónica, la túnica media es totalmente deficiente siendo sustituida por la túnica adventicia (Forbus raphé). La túnica adventicia es más gruesa en las bifurcaciones (0.21mm) en comparación con otros lugares del buque. El grosor medio de la túnica media de ACM en su origen fue $0.12 \mathrm{~mm}$ mientras que el de la túnica adventicia de $0.10 \mathrm{~mm}$. Estos resultados son similares a los que han sido descritos en la literatura para Caucásicos. Es importante la afirmación que las anomalías anatómicas de la ACM son raras. La aparentemente baja frecuencia de los aneurismas de ACM en nigerianos africanos no es debido a sus anomalías o a la histología.

PALABRAS CLAVE: Anomalías; Histología; Arteria cerebral media.

\section{REFERENCES}

Adamson, J.; Humphries, S. E.; Ostergaard, J. R; Voldby, B.; Richards, P \& Powell, J. T. Are cerebral aneurysms atherosclerotic? Stroke, 25(5):963-9, 1994.

Bombay Hospital Institute of Medical Sciences, Department of Neurosurgery, India. Study of The circle of Willis in 1,021 consecutive autopsies. Incidence of aneurysms, anatomical variation and atherosclerosis. Ann. Acad. Med. (Singapore), 22(3):443-6, 1993.

Coutard, M. \& Osborne-Pellegrin, M. Genetic susceptibility to experimental cerebral aneurysms formation in the rat. Stroke, 28(5):1035-41, 1997.

Crompton, M. R. Pathology of ruptured middle cerebral aneurysms with special reference to difference between the sexes. Lancet, 2:421-5, 1962.
Diggs, L. W. \& Brookoff, D. Multiple cerebral aneurysms in patients with sickle cell disease. South. Med. J., 86 (4):377-9, 1993.

Finlay, H. M. \& Ganhan, P. B The layered fabric of cerebral artery fenestrations. Stroke, 25(9):1799-1806, 1994.

Fogelholm, R.; Hernesniemi, J. \& Vapalanti, M. Impact of early surgery on outcome after aneurysmal subarachnoid haemorrhage: a population based study. Stroke, 24:164954, 1993.

Forbus, W. D. On the origin of miliary aneurysm of the superficial cerebral arteries. Bull. Johns Hopkins Hosp., 47:239-84, 1930.

Glynn, L. E. Medial defects in the circle of Willis and their 
IDOWU, O. E.; SHOKUNBI, M. T.; MALOMO, A .O. \& AKANG, E. E. U. Anomalies, aneurysm and histology of the middle cerebral artery in Nigerian Africans. Int. J. Morphol.,26(4):1023-1027, 2008.

relation to aneurysm formation. J. Pathol. Bacteriol., 51:213-22, 1940.

Hosada, K.; Fujita, S.; Kawaguchi, T. \& Hamano, S. Saccular aneurysms of the proximal M1 segment of the middle cerebral artery. Neurosurgery, 36(5):1051, 1995.

Howng, S. L.; Hung, T. P.; Kwan, A. L. \& Lin, C. I. Intracranial Aneurysms In Taiwan. J. Formosan Med. Assoc. Suppl. 2:573-80, 1995.

Inagawa, T.; Tokuda, Y.; Ohbayashi, N.; Takaya, M. \& Moritake, K. Study of aneurysmal subarachnoid haemorrhage in Izumo City, Japan. Stroke, 26:761, 1995.

Jain, K. K. Some observations on the anatomy of the middle cerebral artery. Can. J. Surgery, 7:134-9, 1964.

Johnson, T. O. Arterial blood pressures and hypertension in an urban African population sample. Br. J. Prev. Soc. Med., 25:26-33, 1971.

Juvela, S.; Hillbam, M.; Numminen, H. \& Koskinen, P. Cigarette smoking and alcohol consumption as risk factors for aneurysmal subarachnoid haemorrhage. Stroke, 24:639-46, 1993.

Knekt, P.; Reunanen A.; \& K. Aho, K. Risk factors for subarachnoid haemorrhage in a longitudinal population study. J. Clin. Epidemiol., 44:933-9, 1991.

Laadzinki, P.; Koper, R.; Malizewski, M. \& Majchrzak, H. Views on the etiology and pathogenesis of intracranial aneurysms. Neurologia i Neurochirurgia Polska, 30(4):649-57, 1996.

Longstreth, W. T. Jr.; Nelson, L. M.; Keepsell T. D. \& Van Belle, G. Clinical course of spontaneous subarachnoid haemorrhage: a population based study in King Country, Washington. Neurology, 43:712-8, 1993.

Oyesiku, N. M.; Barrow, D. L.; Eckman, J. R.; Tindal, S. C. \& Colohan, A. R. Intracranial aneurysms in sickle cell anaemia: clinical features and pathogenesis. $J$. Neurosurg., 75:356-63, 1991.

Phillips, L. H.; Whisnant, J. P.; O’Fallen, W. M. \&. Sundt, T. M. J. R. The unchanging pattern of subarachnoid haemorrhage in a community. Neurology, 30:1034-40, 1980.

Picard, L.; Bracard, S.; Anxionnat, R.; Prada, E.; Per, A.; Burdin, D.; Hummer, M.; Audibert, G.; Marchal, J. C.
\& Auque, J. Endovascular treatment of intracranial aneurysms. Ann. Fr. Anesth. Reanim., 15(3):348-53, 1996.

Rinne, J.; Hernesniemi, J.; Niskanem, M. \& Vapalaliti, M. Analysis of 561 patients with 690 middle cerebral artery aneurysms: anatomic and clinical features as correlated to management outcome. Neurosurgery, 38: 2-11, 1996.

Sacco, R. L.; Wolf, P. A. \& Bharucha, N. E. Subarachnoid and intracerebral haemorrhage: natural history, prognosis, and percussive factors in the Framingham Study. Neurology, 34:847-854, 1984.

Schievink, W. I.; Katzmann, J. A.; Piepgras, D. G. \& Schaid, D. J. Alpha-1- Antitrypsin phenotypes among patients with intracranial aneurysms. J. Neurosurg., 84:781-784, 1996.

Schievink, W. I.; Wijdicks, E. F. M.; Parisi, J. E.; Piepgras, D. G. \& Whisnant, J. P. Sudden death from aneurysmal subarachnoid haemorrhage. Neurology, 45:871-4, 1995.

Stehbens, W. E. Histopathology of cerebral aneurysms. Arch. Neurol., 8:272-285, 1963.

Stehbens, W. E. Etiology of intracranial berry aneurysms. J. Neurosurg., 70:823-31, 1989.

Taylor, C. L.; Yuan, Z.; Selman, W. R.; Ratcheson, R. A. \& Rinn, A. A. Cerebral arterial aneurysm formation and rupture in 20,767 elderly patients: hypertension and other risk factors. J. Neurosurg., 83(5):812-9, 1995.

Taylor, G. O. \& Agbedana, E. O. Comparative study of plasma High-Density Lipoprotein cholesterol in two groups of Nigerians of different socio-economic status. A fr. $J$. Med. Med. Sci., 12:23-8, 1983.

Correspondence to:

Idowu, O. E.

Division of Neurosurgery

Department of Surgery

Lagos State University College of Medicine, Ikeja, Lagos,

NIGERIA

E-mail:oeidowu412@yahoo.com

Received: 19-03-2007

Accepted: 22-09-2008 
